Reprod. Nutr. Dévelop., 1980, 20 (4 B), 1339-1349.

\title{
Origin and utilization of volatile fatty acids in the rat
}

\author{
par C. RÉMÉSY, C. DEMIGNÉ, F. CHARTIER
}

Laboratoire des Maladies métaboliques, I. N. R. A., Theix, 63110 Beaumont, France

Summary. The arteriovenous differences in the caecum of the rat have been compared for volatile fatty acids (VFA) and for electrolytes. Our results suggest the possibility of an exchange between VFA and chloride at the level of the caecal wall, rather than a net exchange between VFA and bicarbonate; however, the role of bicarbonate or $\mathrm{Cl}^{-}$at the cellular level is still unknown. Acetate uptake by the liver was enhanced when acetate in the afferent plasma was increased in fed as in starved rats, showing that acetyl CoA synthetase was still active during starvation. A release of endogenous acetate was only observed in situations of very active ketogenesis (starvation at the end of pregnancy). In physiological conditions, propionate and butyrate reaching the liver were almost quantitatively removed. However, butyrate was taken up by the liver at a higher rate than propionate after intracaecal loads. Propionate was very efficiently utilized as a glucogenic substrate and without noticeable disturbance of lactate metabolism. After administration of acetate loads in starved rats, hepatic ketogenesis increased slightly. There was a marked difference between ketogenesis from butyrate in fed and starved rats. The low ketogenesis from butyrate in the fed rats stressed the important role of metabolic pathways of acetyl-CoA utilization in the control of ketogenesis. In contrast to alanine or lactate, propionate was poorly antiketogenic in the rat.

\section{Introduction.}

The volatile fatty acids (VFA) formed by microbial fermentation in the digestive tract represent a large proportion of the energy requirements of herbivorous mammals. Only acetate is present in significant amounts in the peripheral blood of nonherbivores and at concentrations lower than in herbivores (Rémésy and Demigné, 1974).

Surprisingly, there is no evident difference in blood concentrations between fed and starved non-herbivores (Knowles et al., 1974). In the rat, the main site of VFA production and absorption is the large intestine, particularly the cæcum (Rémésy and Demigné, 1976). Besides digestive origin, it has frequently been suggested that endogenous acetate could be produced by various tissues (Knowles et al., 1974 ; Seufert ef al., 1974 ; Buckley and Williamson, 1977).

Little is known about the processes of VFA absorption and metabolism. There is still no theory on the mechanism of VFA absorption which has really gained wide acceptance, particularly in relation to the absorption of cations. In addition, the meta- 
bolic fate of the absorbed VFA has seldom been studied, even though acetate has an important metabolic role as a substrate for lipogenesis or energy production and as an effector for gluconeogenesis (Whitton, Rodrigues and Hems, 1979). Propionate and butyrate are efficient substrates of gluconeogenesis and ketogenesis, respectively.

In the present work, VFA absorption was compared to net transfer of various electrolytes. In the second part, hepatic uptake of acetate, propionate and butyrate and their effects on gluconeogenesis were studied in fed or starved rats.

\section{Material and methods.}

Animals and diets. - Sherman rats weighing 200 to $250 \mathrm{~g}$ were fed ad libitum with a standard chow (Sanders, Juvisy s/Orge) containing percentages of the following : cereals 62, seed cake 28, molasses 5, salts and vitamin 5. Between 9 and 11 a.m. after overnight feeding or 24-hour fasting, about $1 \mathrm{ml}$ of blood was sampled from the caecal vein and then from the aorta of rats anesthetized with Nembutal $(40 \mathrm{mg} / \mathrm{kg})$; these samples were used in absorption studies. For studies on hepatic metabolism, blood was taken from either the hepatic vein or the portal vein or from the portal vein and then the aorta. VFA loads ( $3 \mathrm{mmoles} / \mathrm{kg}$ of body weight) were effected in the caecum ( 4 to $5 \mathrm{ml}$ of a solution of $150 \mathrm{mM}$ sodium salts) $15 \mathrm{~min}$ after the onset of the anesthesia ; blood and tissue were sampled $15 \mathrm{~min}$ after the load. Liver samples were obtained by the "freeze-clamping » method.

Metabolite determination. - Measurement of VFA and minerals in the plasma and the caecal contents have been previously described (Demigné, Rémésy and Rayssiguier, 1980). Plasma and liver metabolites were determined by enzymatic methods (Rémésy, Demigné and Aufrère, 1978).

Calculations. - It was assumed that the portal vein and the hepatic artery represent 70 and 30 p. 100, respectively, of the hepatic blood flow (Greenway and Stark, 1971). Afferent plasma concentrations were thus : 0.7 (portal vein) +0.3 (aorta), the hepatic balance being the difference between the hepatic vein and the afferent plasma. The percentage of hepatic uptake showed the following ratio : hepatic balance/afferent plasma. Digestive absorption and hepatic uptake were compared using the ratio : hepatic balance/0.7 (portal vein-artery).

\section{Results and discussion.}

Caecal absorption of VFA and minerals (fig. 1). - VFA concentrations were high in the caecum of fed rats (180 $\mathrm{mM}$; acetate 60 , propionate 26 , butyrate 14 p. 100). The transfer of VFA across the caecal wall was proportional to VFA concentrations in the caecal contents (Rémésy and Demigné, 1976). The mechanism of this transfer has not been entirely elucidated (transfer in an undissociated form or in a dissociated form with various anion or cation exchanges). The sum of the absorbed cations was generally higher than the absorbed VFA. In addition, the magnitude of $\mathrm{Cl}^{-}$secretion was comparable to VFA absorption ; this release in the caecal content could be considered as a counter-anion transport for VFA absorption. The striking drop in blood $\mathrm{pH}$ 
in the caecal vein probably cannot be entirely explained by the metabolism of the caecal wall, and a part of venous blood acidification might be related to organic acid absorption. Except for $\mathrm{Na}^{+}$, net transfer of various electrolytes and $\mathrm{H}^{+}$across the caecum wall is effected along a favourable gradient. The role of bicarbonate exchanges in these processes was not assessed in our experiments with fermentation at $\mathrm{pH} 6$.
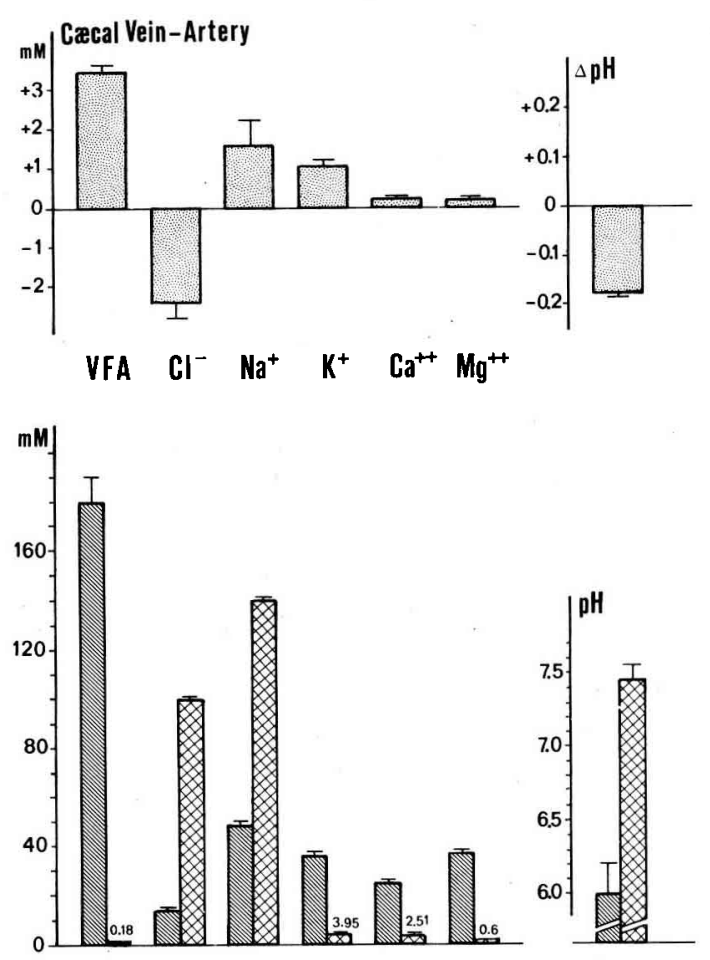

$\mathbb{N}$ Cæcal Content

FIG. 1. - A comparison of arteriovenous and caecal content concentrations of volatile fatty acids, chloride, sodium, potassium, calcium, magnesium and of $\mathrm{pH}$ in rats fed a seed cake-cereal commercial chow. Each value is the mean \pm SEM for 10 rats.

Coupled anion transfer could be non-specific for $\mathrm{Cl}^{-}$and $\mathrm{HCO}_{3}^{-}$, but might concern either VFA and $\mathrm{HCO}_{3}^{-}$(McNeil, Cummings and James, 1979) or VFA and $\mathrm{Cl}^{-}$ (suggested by our results), as $\mathrm{Cl}^{-}$is always secreted in the presence of low concentrations in the caecal contents.

Absorption of the un-ionized form of VFA is certainly important in acidic caecal conditions, but VFA are probably also absorbed as anions either in exchange with $\mathrm{HCO}_{3}^{-}$or $\mathrm{Cl}^{-}$or in association with $\mathrm{Na}^{+}$. In physiological conditions ( $\mathrm{pH}$ in the range of 6.0 to 7.0), the last two processes seemed to operate simultaneously. However, the staechiometry of this coupled transfer and the precise mechanisms involved at 
the cellular level are stil unknown. According to Lamers (1975), permeability to acids in the anionic form is higher at the serous barrier than at the luminal barrier. The role of the caecum in $\mathrm{K}^{+}, \mathrm{Mg}^{++}$and $\mathrm{Ca}^{++}$absorption has been discussed by Demigné, Rémésy and Rayssiguier (1980).

Digestive and hepatic VFA balances in normally fed rats (fig. 2). - Only acetate was present in noticeable amounts in the arterial plasma. Net VFA absorption in the portal vein was proportional to VFA concentrations in the digestive contents. The liver removed about 50 p. 100 of the acetate reaching it; this represented about 75 p. 100 of the absorbed acetate. Hepatic uptake of propionate and butyrate was extremely efficient ( 85 to 90 p. 100) ; thus, the absorbed propionate and butyrate were nearly quantitatively removed by the liver.

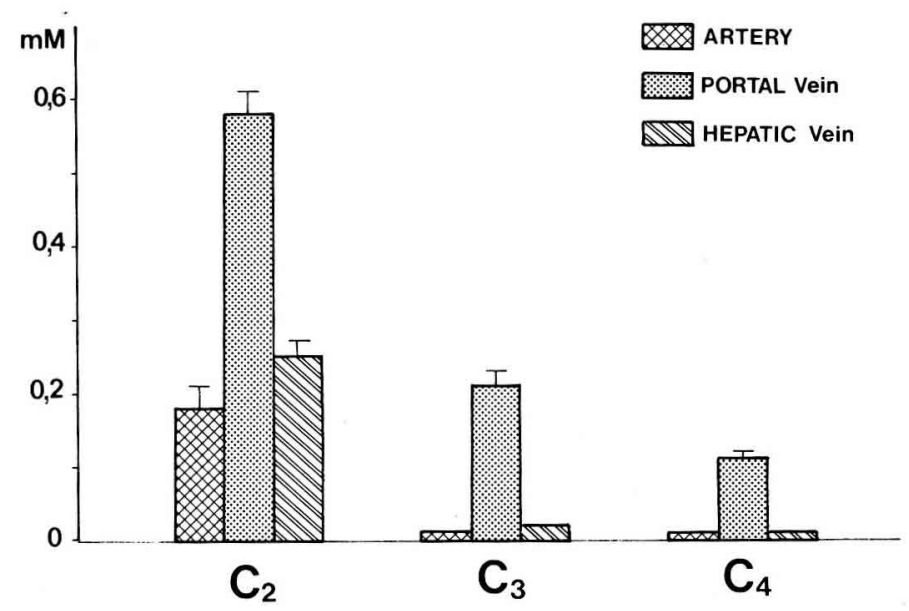

FIG. 2. - Comparison of acetate $\left(C_{2}\right)$ propionate $\left(C_{3}\right)$ and butyrate $\left(C_{4}\right)$ concentrations in the artery, portal vein and hepatic vein. Each value is the mean $\pm S E M$ for 12 rats.

Hepatic acetate balance in various afferent blood conditions (fig. 3). - Acetate uptake by the liver increased with afferent blood concentrations ; in fed rats, the uptake percentage was very similar in control rats or in those receiving an intracaecal load of $3 \mathrm{mmoles} / \mathrm{kg}$. So, in agreement with the results of Buckley and Williamson (1977), portal vein-hepatic difference was linearly related to the portal vein acetate concentration. When afferent acetate concentrations were very low (caecumectomized rats), there was no significant uptake by the liver.

Despite striking changes in hepatic metabolism (high ketogenesis and acetyl CoA production from long-chain fatty acids), the hepatic uptake of acetate in starved animals was quite similar during acetate load. In 20-day pregnant rats starved $24 \mathrm{hr}$ and exhibiting a very high ketogenesis (Whitelaw and Williamson, 1977), some acetate was released by the liver, but the amount was small as compared to the quantities of fatty acid metabolized as ketone bodies. In normal starved rats there was no significant release of acetate. 

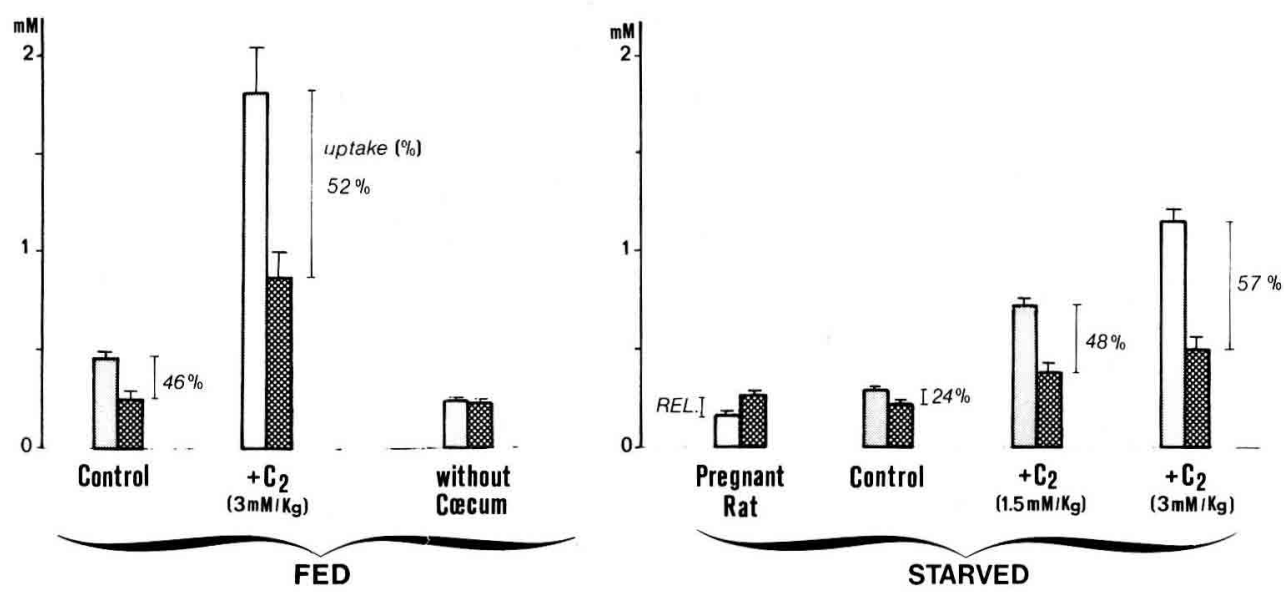

\section{$\square$ AFFERENT Plasma}

㕠EFFERENT Plasma

FIG. 3. - Hepatic balance and hepatic percentage of acetate uplake in fed or starved rats. Caecumectomy was effected according to Rémésy and Demigné (1976). For calculation of afferent plasma concentration see the text. Each value is the mean \pm SEM for 8 rats.

The liver is considered as freely permeable to acetate. This agrees with the relatively constant uptake we observed, and acetate activation did not seem to be a limiting process. In contrast to the ruminant (Ballard, Hanson and Kronfeed, 1969), active cytosolic acetate thiokinase is found in the rat ; the $\mathrm{Km}$ for acetate of the mitochondrial thiokinase is very high, while the cytosolic enzyme has a high affinity for acetate (Scholte and Groot, 1975). Indeed, the data of Dietschy and McGarry (1974), concerning hepatic cholesterogenesis and ketogenesis, also suggest that acetate activation is mainly cytosolic. In starved rats, the acetate uptake seemed poorly modified despite the decrease of lipogenesis and cholesterogenesis, in contrast with the findings of Murthy and Steiner (1972). In these conditions, the metabolic fate of cytosolic acetyl CoA is still questionable.

In the liver, mitochondrial acetate release depends mainly on the activity of the acetyl CoA deacylase and of acetyl CoA concentrations. Deacylase $\mathrm{Km}$ is about $0.5 \mathrm{mM}$ (Grigat et al., 1979) ; this value seems lower than normal acetyl CoA concentrations in mitochondria, which increase during fasting (Soboll ef al. ; 1976). In addition, fasting does not alter the acetyl CoA deacylase activity (Murthy and Steiner, 1973). These data and our results suggest that the increased availability of acetyl CoA in mitochondria during starvation does not induce a noticeable production of endogenous acetate, which always seems to be limited, except in diabetic animals (Buckley and Williamson, 1977). In this last case, the decrease of hepatic thiokinase activity (Kornacker and Lowenstein, 1965) and the increase of acetyl CoA deacylase (Seufert ef al., 1978) permitted a production of endogenous acetate despite the high concentrations in the afferent plasma.

Hepatic balance of propionate and butyrate (fig. 4). - The hepatic uptake of these VFA was extremely efficient in the normally fed rats, thus permitting a practically 
quantitative removal of the absorbed propionate and butyrate. Following VFA loads in the caecum, plasma concentrations of propionate or butyrate afferent to the liver were about $1 \mathrm{mM}$; in these conditions, the efficiency of propionate uptake decreased from 86 to 52 p. 100, while butyrate uptake was poorly affected. In fact, portal propionate and butyrate concentrations ranged between 0.1 and $0.3 \mathrm{mM}$ with most of the diets. However, those including high proportions of readily fermentable carbohydrates, such as lactose and crude potato-starch, induced caecal fermentation rich in propionate ; therefore, the absorbed propionate might be incompletely removed by the liver with the appearance of small amounts of propionate in the arterial plasma.
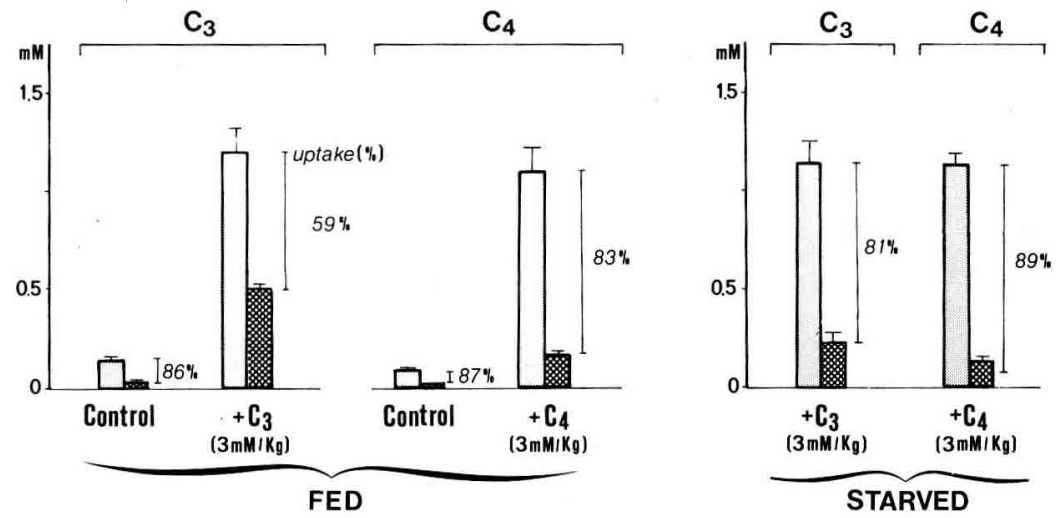

$\square$ AFFERENT Plasma

眓 efferent Plasma

FIG. 4. - Comparison of hepatic propionate or butyrate uptake in fed or starved rats. Treated rats received an intracaecal load of volatile fatty acids ( 3 mmoles $/ \mathrm{kg}$ ). Blood was sampled $15 \mathrm{~min}$. after intracaecal injection of volatile fatty acids. Results of control starved rats are not shown as afferent propionate and butyrate are extremely reduced. Values are means ( \pm SEM) for 8 rats.

Propionate was a minor substrate for hepatic gluconeogenesis in starved rats. However, with caecal loads, hepatic uplake was more efficient than in fed rats, as for lactate and alanine. In contrast, a high percentage of butyrate was always removed, whatever the portal concentrations or the nutritional state.

The VFA were almost completely ionized at blood $\mathrm{pH}$, and the diffusion of the unionized form could hardly account for the high propionate or butyrate uptake. Butyrate is partly bound to plasma albumin in the rat (more is bound in the ruminant), while no binding was observed for propionate (Rémésy and Demigné, 1974). In addition, before mitochondrial activation, butyrate possibly binds to a cytosolic protein, distinguishable from the FABP and having a low affinity for propionate (Morioka and Ono, 1978). The exact mechanism of propionate and butyrate penetration across the cellular and mitochondrial membranes is unknown ; however, it is clear that mitochondrial entry is not strictly dependent on an acylcarnitine transferase system. The differences in propionate and butyrate uptake are still speculative ; could :

- the rate of intracellular or (and) intramitochondrial penetration, with the possible implications of different monocarboxylate carriers, differ ; 
— there be a limiting step in fed rats for propionate metabolization, but not for butyrate :

- propionate activation depend on a relatively specific propionyl CoA synthetase, while butyrate would depend on a distinct medium-chain acyl CoA synthetase (Groot, 1975) with possibly different kinetic properties.

Effects of VFA on gluconeogenesis (figs. 5, 6). - Acetate and butyrate are not glucogenic precursors, but butyrate could stimulate gluconeogenesis via the increased
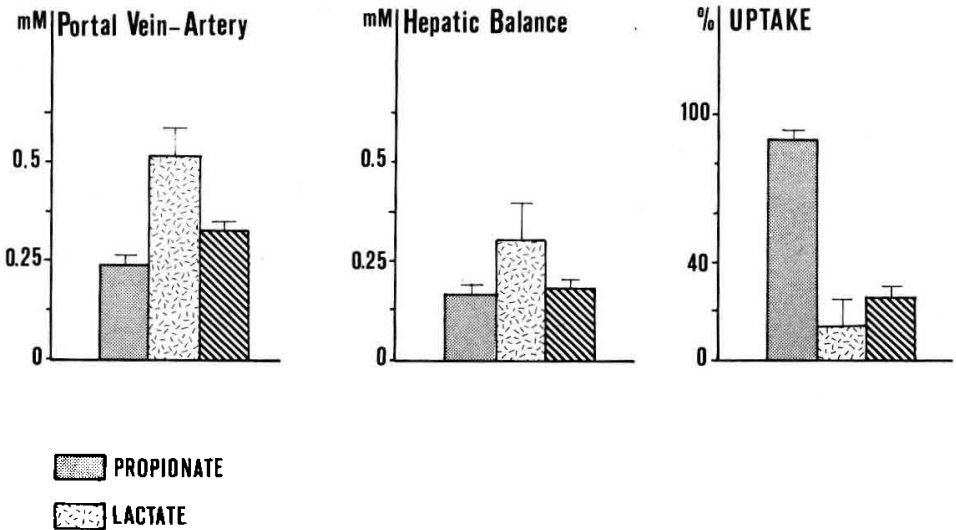

ALANINE

FIG. 5. - Digestive and hepafic balance of propionote, lactafe and alanine in fed control rats. For calculation of the percentages of hepatic uptake see the text. Values are means $( \pm S E M)$ for 10 rats.

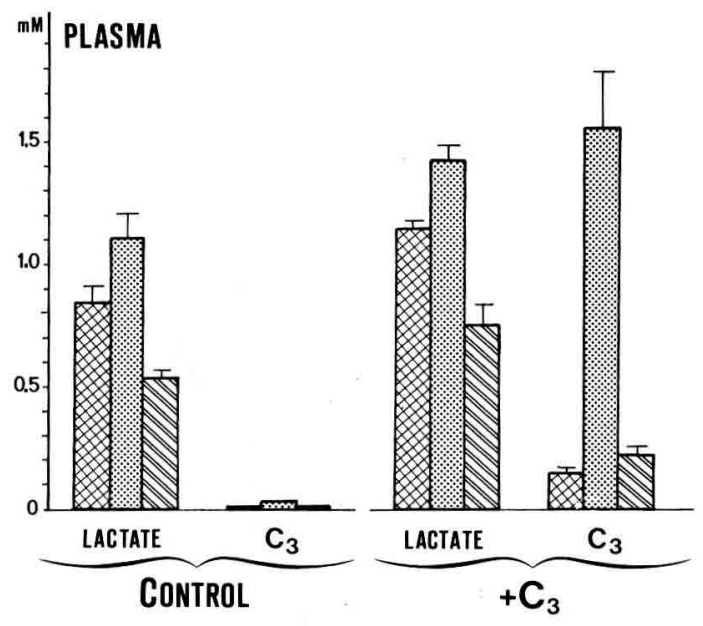

Artery

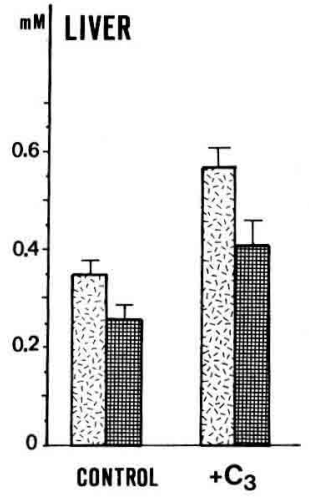

Lactate

Malate

FIG. 6. - Hepatic bolonce of lactate and propionate and liver lactate and malate concentration in starved control rats or in starved rats receiving an intracaecal load of propionate $(3 \mathrm{mmoles} / \mathrm{kg})$. Values are means ( $\pm S E M)$ for 8 rats. 
availability of mitochondrial acetyl CoA and thus increase the activity of pyruvate carboxylase. However, after butyrate loads, we observed no higher uptake of lactate in starved rats, and the marked hyperglycemic effect obtained in fed rats could correspond to glycogenolysis (results not shown).

In rats fed diets allowing substantial caecal fermentation, propionate was one of the main $\mathrm{C}_{3}$ units removed by the liver besides lactate and alanine. The high percentage of hepatic uptake of propionate ( 90 vs 15 to 20 p. 100 for lactate and alanine) largely accounted for this fact, which is usually underestimated in metabolic studies. In starved rats, the digestive supply and metabolic role of propionate was reduced, while the hepatic uptake of lactate and most glucogenic amino acids increased. Propionate in starved rats did not decrease lactate uptake, in spite of a substantial rise in intrahepatic lactate and malate. Propionate seemed a particularly efficient glucogenic substrate as its metabolism did not depend on the activity of the pyruvate carboxylase/pyruvate dehydrogenase couple. In addition, the $\mathrm{C}_{4}$ units exited out of the mitochondria as malate, thus avoiding a possible interference with ureogenesis at the level of aspartate metabolism. This last feature could account for the reduced use of lactate with a high supply of amino acids (Rémésy, Demigné and Aufrère, 1978).

Effects of VFA on ketogenesis (fig. 7). - As shown by previous works (Dietschy and McGarry, 1974), acetate entering the liver is not the most readily available substrate for ketogenesis. Basal ketogenesis in the fed rats was not modified by the administration of acetaie which slightly increased the ketone bodies in the plasma of the starved rats. However, as acetate was markedly antilipolytic (arterial FFA; controls : $0.80 \mathrm{mM}$; acetate load : $0.53 \mathrm{mM}$ ), the contribution of acetate to hepatic ketogenesis was probably fairly important. The site of the synthesis of acetyl CoA from acetate entering ketogene-

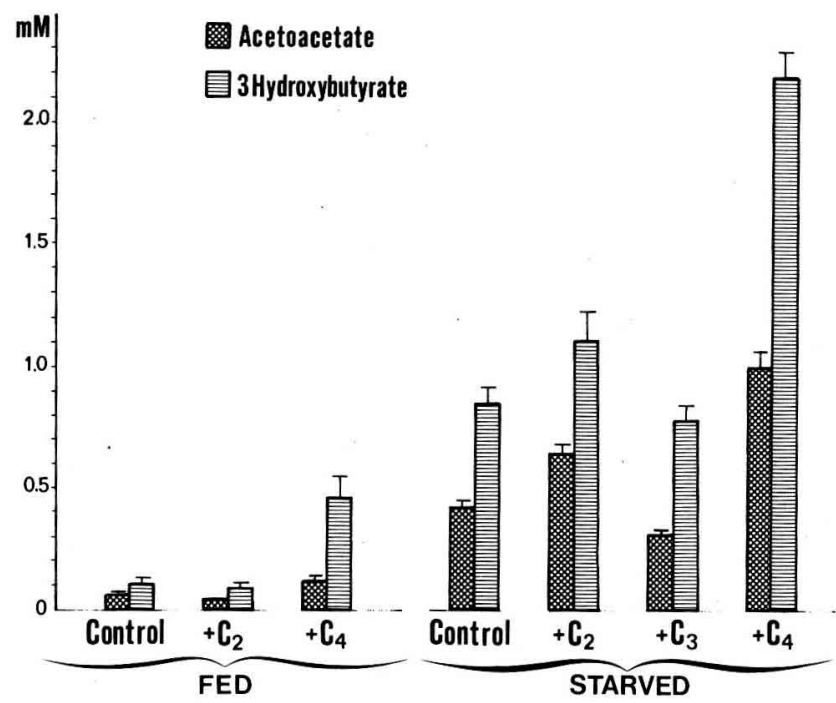

FIG. 7. - Effects of volatile fotty acids on ketone body concentrations in arterial plasma. Volatile fatty acids were injected in the caecum ( $3 \mathrm{mmoles} / \mathrm{kg})$ and blood was sampled $15 \mathrm{~min}$. after injection. Values are means $( \pm$ SEM) for 8 rats. 
sis remains questionable. Acetyl CoA is synthesized either after mitochondrial or cytosolic activation. The transfer of acetyl CoA into the mitochondria for ketogenesis would be effected against a high concentration gradient (Soboll et al., 1976) ; in fact, the interacti ons of various acetyl CoA pools in the cell are barely known.

Butyrate is a more efficient ketogenic substrate than long-chain fatty acids; it is activated in the mitochondria, thus no reesterification occurs and butyrate entry escapes a possible regulation by the acyl carnitine transferase system. In addition, during ketogenesis from butyrate, a greater part of the $C_{2}$ terminal unit contributes directly to the formation of the carbonyl moiety of acetoacetate than during ketogenesis from long-chain fatty acyl CoA (Lopes-Cardozo, 1978). However, even for butyrafe, ketogenesis can be described as an overflow mechanism : the acetyl groups are only diverted towards ketone body synthesis when acetyl CoA production increases beyond the capacity of the Krebs cycle and the outflow for cytosolic synthesis (mainly lipogenesis). Thus, in our fed animals having high capacities of acetyl CoA utilization, ketogenesis from butyrate was very low. In fact, butyrate could even be a more efficient precursor of acetyl units for lipogenesis and cholesterogenesis than glucose or acetate itself (Dietschy and McGarry, 1974). In contrast, ketogenesis with butyrate was high during starvation, and Williamson et al. (1974) have shown that ketogenesis from butyrate is independent from the availability of long-chain fatty acids. However, these authors, using an unphysiological route, administered very high doses of butyrate, and thus failed to observe marked differences in ketogenesis from butyrate between fed and starved rats. Our results, therefore, stress the important role of metabolic pathways of acetyl CoA utilization (Krebs cycle, exit towards the cytosol) on the control of ketogenesis.

Propionate administered to starved rats hardly lowers ketogenesis. This fact has been observed by Williams ef al. (1971), but is rather surprising as it contrasts with the well-known antiketogenic effect of glucogenic substrates: lactate and alanine in the rat (Krebs et al., 1974 ; Ozand et al., 1978) and propionate in the ruminant (Demigné and Rémésy, 1977). It seems that an unequivocal antikefogenic effect with propionate is only seen with species having a cytosolic phosphoenolpyruvate carboxykinase in the liver.

Journées Ingestion-Digestion-Absorption de l'Association française de Nutrition, Paris, 15-16 novembre 1979.

Résumé. L'absorption des acides gras volatils par le cæcum de rat a été comparée à celle des principaux électrolytes. La possibilité d'un échange acides gras volatils (AGV)-chlorures, au niveau de la paroi cæcale plutôt que d'un échange AGV-bicarbonate, est discutée. Le foie capte d'autant plus d'acétate que la concentration dans la veine-porte s'élève et ceci même à jeun ce qui prouve que l'acétyl CoA synthétase est toujours active. La production d'acétate endogène est peu importante et détectable seulement dans le cas de fortes cétogenèses (rattes gestantes à jeun). Le propionate est moins capté que le butyrate en cas de surcharges, il constitue un excellent substrat pour la néoglucogenèse sans modifier notablement l'utilisation du lactate. L'acétate, qui est activé principalement dans le cytosol, est peu cétogène même chez le rat à jeun. Il existe une différence très marquée entre la cétogenèse à partir du butyrate chez le rat nourri ef à jeun. La faible cétogenèse à partir du butyrate chez l'animal nourri montre l'importance des voies métaboliques de l'utilisation de l'acétate dans la régulation de la cétogenèse. A la différence de l'alanine ou du lactate, le propionate est très faiblement anticétogène chez le rat. 


\section{References}

BALLARD F. J., HANSON R. W., KRONFELD D. S., 1969. Gluconeogenesis and lipogenesis in tissue from ruminant and non-ruminant animals. Fed. Proc., 28, 218.

BUCKLEY B. M., WILLIAMSON D. H., 1977. Origin of blood acetate in the rat. Biachem. J., 166, 539-545.

DEMIGNÉ C., RÉMÉSY C., 1977. La cétogenèse chez les ruminants à jeun : influence des acides gras volatils, du glucose et de l'alanine. Ann. Biol. anim. Bioch. Biophys., 17, 887-895.

DEMIGNÉ C., RÉMÉSY C., RAYSSIGUIER Y., 1980. Effect of fermentable carbohydrates on volatile fatty acids, ammonia and mineral absorption, in the rat caecum. Reprod. Nutr. Dévelop., 20, 1351-1359.

DIETSCHY J. M., McGARRY J. D., 1974. Limitations of acetate as a substrate for measuring cholesterol synthesis in liver. J. biol. Chem., 249, 52-58.

GREENWAY G. V., STARK R. D., 1971. Hepatic vascular bed. Physiol. Rev., 51, 23-65.

GRIGAT K. P., KOPPE K., SEUFERT C. D., SOLING H. D., 1979. Acetyl-coenzyme A deacylase activity in liver is not an antifact. Biochem. J., 177, 77-79.

GROOT P. H., 1975. The activation of short-chain fatty acids by the soluble fraction of guinea-pig heart and liver mifochondria. Biochem. biophys. Acta, 380, 12-20.

KNOWLES S. E., JARRETT I. G., FILSELL O. H., BALLARD F. J., 1974. Production and utilization of acetate in mammals. Biochem. J., 142, 401-411.

KORNAKER M. S., LOWENSTEIN J. M., 1965. Citrate and the conversion of carbohydrate into fat. Activities of citrate cleavage enzyme and acetate thiokinase in livers of normal and diabetic rats. Biochem. J., 95, 832-837.

KREBS H. A., CORNELL N. W., LUND P., HEMS R., 1974. Isolated liver cells as experimental materials, 726-750. In LUNDQUIST F., TYGSTRUP N., Regulation of hepatic metabolism. Munksgaard Eds, Copenhagen.

LAMERS J.M. L., 1975. Some characteristics of monocarboxylic acid transfer across the cell membranes of epithelial cells from rat small intestine. Biochim. biophys. Acta, 413, 265-276.

LOPES-CARDOZO M., 1978. Regulation of ketogenesis in isolated rat liver mitochondria, 41-50. In SÖLING H. D., SEUFERT C. D., Biochemical and chemical aspects of ketone body metabolism. Georg Thieme Publ., Stuttgart.

MCNEIL N. I., CUMMINGS J. H., JAMES W. P. T., 1979. Rectal absorption of short-chain fatty acids in the absence of chloride. Gut, 20, 400-403.

MORIOKA K., ONO T., 1978. Butyrate binding protein from rat and mouse liver. J. Biochem., 83, 349-356.

MURTHY V. K., STEINER G., 1972. Hepatic acetic thiokinase : Possible regulatory step in lipogenesis. Metabolism, 21, 213-221.

MURTHY V. K., STEINER G., 1973. Hepatic acetate levels in relation to altered lipid metabolism. Metabolism, 22, 81-84.

OZAND P. T., REED D. W., HAWKINS R. L., STEVENSON J. H., TILDON J. T., CORNBLATH M., 1978. Effect of $L$ alanine infusion on gluconeogenesis and ketogenesis in the rat in vivo. Biochem. J., 170, 583-591.

RÉMÉSY C., DÉMIGNÉ C., 1974. Determination of volatile fatty acids after ethanolic extraction. Biochem. J., 141, 85-91.

RÉMÉSY C., DÉMIGNÉ C., 1976. Partition and absorption of volatile fatty acids in the alimentary canal of the rat. Ann. Rech. vét., 7, 39-55.

RÉMÉSY C., DEMIGNÉ C., AUFRÈRE J., 1978. Interorgan relationships between glucose, lactate and amino acids in rats fed on high carbohydrate or high protein diets. Biochem. J., 170, $321-329$.

SEUFERT C. D., GRAF M., JANSON G., KUHN A., SÖLING H. D., 1974. Formation of free acetate by isolated perfused livers from normal starved and diabetic rats. Biochem. Biophys. Res. Comm., 57, $901-909$.

SEUFERT C. D., GRIGAT K. P., KOPPE K., SÖLING H. D., 1978. Regulation of formation of ketone bodies and acetate in rat liver, 23-40. In SÖLING H. D., SEUFERT.C. D., Biochemical and clinical aspects of ketone body metabolism, Georg Thieme Publ., Stuttgart. 
SCHOLTE H. R., GROOT P. H. E., 1975. Organ and intracellular localization of short-chain acylCoA synthetases in rat and guinea-pig. Biochem. biophys. Acta, 409, 283-296.

SOBOLL S., SCHOLZ R., FREISL M., ELBERS R., HELDT H. W., 1976. Distribution of metabolites between mitochondria and cytosol of perfused liver, 29-40. In TAGER J. M., SÖLING H. D. and WILLIAMSON J. R., Use of isolated liver cells and kidney fubules in metabolic studies, NorthHolland Publ. Co., Amsterdam.

WHITELAW E., WILLIAMSON D. H., 1977. Effects of lactation on ketogenesis from oleate or butyrate in rat hepatocytes. Biochem. J., 164, 521-528.

WHITTON P. D., RODRIGUES L. M., HEMS D. A., 1979. Stimulation by acetate of gluconeogenesis in hepatocyte suspensions. FEBS Left., 98, 85-87.

WILLIAMS D. L., SPRAY G. H., HEMS R., WILLIAMSON D. H., 1971. Metabolic effects of propionate in normal and vitamin B12-deficient rats. Biochem. J., 124, 501-507.

WILLIAMSON D. H., ELLINGTON E. V., ILIC V., SAAL J., 1974. Hepatic effects of saturated or unsaturated short-chain fatty acids and the control of ketogenesis in vivo, 191-206. In LUNDQUIST F., TYGSTRUP N., Regulation of hepatic metabolism, Munksgaard Eds, Copenhagen. 